\title{
The clinical spectrum of HTLV-1 infection
}

\author{
Davi Tanajura', Abraão Neto', Isadora Siqueira², Valéria Gusmão', Paulo Oliveira', Silvana Giozza', Neviton Castro', \\ Natalia Carvalho', Silvane Santos ${ }^{1}$, Edgar M Carvalho ${ }^{1,2,3^{*}}$
}

From 17th International Conference on Human Retroviruses: HTLV and Related Viruses

Trois Ilets, Martinique. 18-21 June 2015

The Human T lymphotropic virus type 1 (HTLV-1) infection is neglected mainly due to the concept that it is associated with a low morbidity. However, a few reports have shown that a large percentage of HTLV-1 infected subjects have signs and symptoms of a variety of diseases. Nevertheless the relationship between the cause and effect needs to be proven. The HTLV-1 associated myelopathy (HAM/TSP) and adult T-cell leukemia (ATL), the main disease associated to HTLV-1, are characterized by high proviral load and lymphocyte activation. Moreover the exaggerated inflammatory response and proviral load are markers of diseases associated with HTLV-1. In this study we compare the frequency of sicca syndrome, chronic periodontal disease (CPD), HTLV-1 associated over reactive bladder (HTLV-1 $\mathrm{OAB})$, artropathy and erectile dysfunction (ED) in HTLV-1infected subjects who did not have definitive HAM/TSP with that observed in seronegative controls. The proviral load was measured by real time PCR and production of interferon $-\gamma$ and TNF in supernatants of lymphocyte culture by ELISA. Of the 180 individuals participants of the study, 106 (50.8\%) were female, 56 (31.1\%) had sicca syndrome, 37 (20.5\%) had CPD, 32 (17.7\%) had HTLV-1 OAB, 29 (16.6\%) had HTLV-1 associated arthropathy. Moreover of the 74 males 31 (41.8\%) had ED. All these manifestations were higher $(\mathrm{P}<0.001)$ in HTLV-1 infected subjects than in controls. Proviral load in sicca syndrome, CPD, HTLV-1 $\mathrm{OAB}$ and $\mathrm{ED}$ patients were higher $(\mathrm{P}<0.05)$ than in 78 $(43,3 \%)$ HTLV-1 carriers. Patients with OAB, CPD and sicca syndrome had higher TNF and IFN- $\gamma$ than HTLV1 carriers. The majority of the patients with diseases associated to HTLV1 had at least two of the above diseases. Overall 56,7\% of HTLV-1 infected subjects without

\footnotetext{
* Correspondence: imuno@ufba.br

'Serviço de Imunologia - Hospital Universitário Professor Edgard Santos, Salvador, Bahia, Brazil

Full list of author information is available at the end of the article
}

definitive HAM/TSP or ATL had diseases associated with HTLV1 infection indicating that HTLV-1 is associated with high morbidity.

\section{Authors' details \\ 'Serviço de Imunologia - Hospital Universitário Professor Edgard Santos, Salvador, Bahia, Brazil. ${ }^{2}$ Centro de Pesquisa Gonçalo Muniz - FIOCRUZ, Salvador, Bahia, Brazil. ${ }^{3}$ Faculdade de Medicina da Bahia - UFBA, Salvador, Bahia, Brazil.}

Published: 28 August 2015

\section{doi:10.1186/1742-4690-12-S1-019}

Cite this article as: Tanajura et al:: The clinical spectrum of HTLV-1 infection. Retrovirology 2015 12(Suppl 1):O19.

\section{Submit your next manuscript to BioMed Central and take full advantage of: \\ - Convenient online submission \\ - Thorough peer review \\ - No space constraints or color figure charges \\ - Immediate publication on acceptance \\ - Inclusion in PubMed, CAS, Scopus and Google Scholar \\ - Research which is freely available for redistribution \\ Submit your manuscript at www.biomedcentral.com/submit}

